\title{
FAKTOR-FAKTOR YANG BERHUBUNGAN DENGAN PERSEPSI TENTANG KESELAMATAN BERKENDARA PADA MAHASISWA PENGENDARA SEPEDA MOTOR
}

\author{
Heni Fa'riatul Aeni*, Rina Ratnaningrum**
}

\begin{abstract}
ABSTRAK
Sepeda motor dapat menjadi ancaman besar terhadap kecelakaan yang terjadi dijalan raya dan menjadi penyumbang korban tertinggi. Laporan Polres Cirebon Kota, laka lantas pada tahun 2013 mengalami kenaikan sebesar 45 persen, yaitu dari 228 kasus pada tahun 2012 menjadi 415 kasus pada tahun 2013. Kecelakaan terbanyak terjadi pada usia produktif yakni usia 20-39 tahun, sedangkan mahasiswa di STIKes Cirebon termasuk ke dalam rentan usia tersebut. Tujuan penelitian ini untuk mengetahui faktor-faktor yang berhubungan dengan persepsi tentang keselamatan berkendara pada mahasiswa pengendara sepeda motor di STIKes Cirebon tahun 2014. Penelitian ini menggunakan instrument penelitian berupa kuesioner. Rancangan penelitian ini adalah desain cross sectional, dengan populasi seluruh mahasiswa pengendara sepeda motor di STIKes Cirebon sebanyak 396 responden dan pengambilan sampel secara asidental (accidental) yaitu sebanyak 77 responden. Data dianalisis secara statistik menggunakan uji chi square.Hasil penelitian ini menunjukan tidak ada hubungan antara usia dengan persepsi tentang keselamatan berkendara $(P v a l u e=$ $1,000)$, tidak ada hubungan antara jenis kelamin dengan persepsi tentang keselamatan berkendara $(P v a l u e=0,902)$, ada hubungan antara motivasi dengan persepsi tentang keselamatan berkendara (Pvalue $=0,039)$, tidak ada hubungan antara pengalaman dengan persepsi tentang keselamatan berkendara (Pvalue $=1,171)$.
\end{abstract}

Kata Kunci: Motivasi, Pengalaman Mengemudi, dan Persepsi

\begin{abstract}
Motorcycles can be a major threat to the accident that occurred on the highway and became the highest contributor to the victim. Cirebon City Police report, lacquer then in 2013 increased by 45 percent, from 228 cases in 2012 to 415 cases in 2013 Accident occurred in the productive age ie 20-39 years of age, whereas students in Cirebon STIKes including to in the vulnerable age. The purpose of this study was to determine the factors associated with the perception of the driving safety of motorcyclists on students in Cirebon STIKes 2014. This research study used a questionnaire instrument. The study design was a cross-sectional design, with the entire student population of motorcyclists in Cirebon STIKes much as 396 respondents and sampling asidental (accidental) is a total of 77 respondents. The data were statistically analyzed using the chi square test. The results of this study showed no association between age and perception of safety driving (pvalue $=1.000$ ), there was no relationship between sex with perceptions about the safety of driving (pvalue $=0.902$ ), there is a relationship between motivation and perception of safety driving (pvalue = 0.039), there is no relationship between the experience of the perception of safe driving (pvalue = 1.171).
\end{abstract}

Keywords: Age, Gender, Motivation, Driving Experience, and Perception

\footnotetext{
* Staf Pengajar Program Studi S1 Kesehatan Masyarakat STIKes Cirebon

** Alumni PSKM STIKes Cirebon Lulus Tahun 2014
} 


\section{PENDAHULUAN}

Saat ini populasi sepeda motor merupakan yang terbanyak dibandingkan kendaraan bermotor lainnya. Populasi sepeda motor hingga akhir 2012, data Korlantas Polri menyebutkan jumlah sepeda motor mencapai 77,7 juta unit. Angka tersebut setara dengan sekitar 83 persen dari total kendaraan yang mencapai 94 juta unit dan terjadi penambahan sebanyak 8 juta maka pada tahun 2013 jumlah

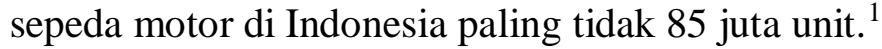

Peningkatan jumlah sepeda motor sejalan dengan peningkatan kecelakaan pengguna sepeda motor. Safety riding merupakan upaya yang dilakukan untuk mengurangi angka kecelakaan lalu lintas dan dampak akibat kecelakan lalu lintas. Kecelakaan lalu lintas merupakan masalah global seiiring dengan terjadinya pergeseran pola penyakit dari penyakit menular ke penyakit tidak menular.

Penilaian WHO bahwa kecelakaan lalu lintas sudah menjadi pembunuh terbesar ketiga di Indonesia, perlu menjadi perhatian bersama. Masyarakat, pengusaha angkutan, pemerintah dan pemangku kepentingan lainnya perlu waspada atas peringatan tersebut. ${ }^{2}$

Kepolisian Republik Indonesia (Polri) mencatat sebanyak 23.385 orang tewas akibat kecelakaan lalu lintas (Lakalantas), selama tahun 2013. Jumlah korban jiwa tersebut 93.578 jiwa dari kasus Lakalantas sepanjang tahun ini. ${ }^{3}$

Faktor penyabab terjadinya kecelakaan terbesar sepanjang enam bulan pertama pada tahun 2013 ternyata diakibatkan oleh faktor pengendara. Didukung data Ditlantas Polda Metro Jaya menyebutkan, sebesar 90,65\% kecelakaan karena faktor manusia. Selebihnya, faktor kendaraan $(8,23 \%)$ dan jalan $(1,11 \%){ }^{4}$

Laporan akhir tahun Polres Cirebon Kota, laka lantas pada tahun 2013 mengalami kenaikan sebesar 45 persen, yaitu dari 228 kasus pada tahun 2012 menjadi 415 kasus pada tahun 2013. Dimana, korban mennggal dunia akibat laka lantas tahun 2013 turun 16 persen, dari 56 orang pada tahun 2012, di tahun 2013 menjadi 48 orang. Pelanggaran lalu lintas tahun 2013 turun sebanyak 21,6 persen yaitu, dari 27.770 kasus pada tahun 2012 menjadi 21.750 kasus pada $2013 .{ }^{5}$ Terdapat fakta lain yang mendukung bahwa korban kecelakaan motor di Kota Cirebon paling banyak (hampir $66,7 \%)$ adalah usia produktif, yaitu usia 20-39 tahun. Posisi kedua pada usia 10-19 tahun (20,37\%), sedangkan usia 40-69 tahun di posisi ketiga sekitar 12,96\%. ${ }^{6}$

Menurut data Dirjen perhubungan darat menyebutkan, penyebab kecelakaan terjadi pada pengendara sepeda motor antara lain karena perilaku dimana masih banyak pengendara yang mengendarai sepeda motor dengan kecepatan terlalu tinggi, tidak mematuhi lalu lintas seperti menerobos lampu merah, dan tidak menggunakan helm saat berkendara. Tingginya kematian akibat kecelakaan lalu lintas pada pengendara mudah salah satunya dipengaruhi oleh rendahnya persepi mereka terhadap resiko keselamatan yang mereka hadapi pada saat berkendara. ${ }^{7}$

Terjadinya suatu kecelakan yang memegang peran penting adalah faktor manusia (human factor) yang berperilaku tidak aman (unsafe act). Perilaku tidak aman tersebut mencerminkan persepsi seseorang atas bahaya dan risiko yang dihadapi, tingkat pengetahuan dan kesadaran untuk berperilaku aman. Persepsi merupakan salah satu penentu perilaku, hal tersebut salah satunya dapat dilihat dari kurangnya kesadaran para pengendara sepeda motor terhadap peraturan lalu lintas yang disebabkan oleh kesalahpahaman persepsi pengendara motor tentang kemungkinan risiko terjadinya kecelakaan.

Penelitian yang dilakukan Faradina tahun 2007 menyebutkan dari total sampel yang diteliti, sebesar $67 \%$ responden memiliki motivasi yang rendah untuk berkendara dengan selamat. Hal ini disebabkan masih dipengaruhi oleh ada tidaknya petugas pengaman lalu lintas. Dalam penelitian itu juga menyimpulkan bahwa dari sebagian besar responden $(82,4 \%)$ pernah mengalami kecelakaan. ${ }^{8}$

Didukung juga peneliti yang dilakukan oleh Yulianti tahun 2010 mengenai persepsi supir angkuatan kota terhadap keselamatan berkendara menyatakan bahwa persepsi pengendara angkutan umum terhadap aspek keselamatan berkendara sangatlah rendah. Dari 69 responden yang diteliti, 85,5\% dinyatakan memiliki motivasi yang kurang baik terhadap keselamatan berkendara dan 34,8\% responden memiliki pengalaman berkendara yang kurang baik. ${ }^{9}$ Sedangkan penelitian yang 
dilakukan oleh Prasilika tahun 2007 yang menyebutkan responden dengan lama mengendarai motor lebih dari 5 tahun memiliki persepsi baik $(80,16 \%)$, sedangkan responden dengan lama mengendarai motor kurang dari 5 tahun memiliki persepsi risiko yang kurang baik (76\%). Selain itu juga terdapat hubungan yang bermakna antara perbedaan pengalaman mengendarai sepeda motor terhadap persepsi keselamatan berkendara. ${ }^{10}$

Menurut Robbins faktor yang berhubungan dengan persepsi seseorang antara lain menurut Robbins faktor individu (pengetahuan, motovasi, pengalaman, dan harapan), sasaran persepsi (orang, benda atau peristiwa), dan situasi persepsi (kondisi lingkungan). ${ }^{11}$

STIKes Cirebon dengan jumlah mahasiswa aktif 935 orang dan mahasiswanya ketika menuju kampus menggunakan kendaraan milik pribadi diantaranya menggunakan sepeda motor sebanyak 396 unit berdasarkan hasil pendataan koordinator masing-masing kelas, jauh lebih banyak dibandingkan dengan mahasiswa yang mengendarai mobil hanya 22 unit. Berdasarkan hasil survei pendahuluan terhadap 50 mahasiswa, terdapat 35 mahasiswa pernah mengalami kecelakaan lalu lintas saat menuju kampus, 6 mahasiswa tidak memiliki SIM (Surat Izin Mengemudi) C, 41 mahasiswa tidak pernah atau jarang sekali untuk memeriksa keadaan kendaraan sepeda motornya sebelum pemakaian, dan 29 unit sepeda motor yang menggunakan satu kaca spion. Dari uraian diatas penulis melakukan penelitian tentang faktor-faktor yang berhubungan dengan persepsi tentang keselamatan berkendara pada mahasiswa pengendara sepeda motor di STIKes Cirebon tahun 2014.

\section{METODE PENELITIAN}

Penelitian ini menggunakan pendekatan kuantitatif dengan desain cross sectional yaitu pengumpulan data sekaligus pada suatu saat. ${ }^{12}$ Populasi dalam penelitian ini adalah seluruh mahasiswa pengendara sepeda motor di STIKes Cirebon sebanyak 396 responden tahun ajaran 2013/2014. Dalam penelitian ini pengambilan sampel dilakukan secara asidental (accidental) yang merupakan cara pengambilan sampel dengan mengambil responden atau kasus yang kebetulan ada atau tersedia. ${ }^{12}$

Penentuan jumlah sampel dilakuan dengan cara sistematik sampling sebanyak 77 mahasiswa. Instrumen yang digunakan dalam penelitian ini adalah kuesioner dengan metode wawancara.

Pada faktor usia, motivasi, pengalaman mengemudi, dan persepsi tentang keselamatan berkendara terlebih dahulu dilakukan transform data dari data numerik ke kategorik dengan normalitas data melalui uji Kolmogorov-Smimov.

Analisis yang digunakan untuk mengetahui hubungan antara variabel bebas (usia, jenis kelamin, motivasi, dan pengalaman mengemudi), dan variabel terikat (persepsi keamanan berkendara) dilakukan dengan uji statistik uji chi square.

\section{HASIL PENELITIAN}

\section{Persepsi tentang keselamatan berkendara}

Persepsi tentang keselamatan berkendara dalam penelitian ini diperoleh bahwa dari 77 responden yang diteliti, mahasiswa pengendara sepeda motor yang mempunyai persepsi baik tentang keselamatan berkendara sepeda motor lebih banyak yaitu sebanyak 57 mahasiswa $(74,0 \%)$ sedangkan sisanya 20 mahasiswa $(26,0 \%)$ mempunyai persepsi kurang baik.

\section{Faktor usia}

Usia responden dalam penelitian ini diperoleh bahwa dari 77 responden yang masuk kategori usia $<25$ tahun lebih banyak yaitu 73 mahasiswa $(94,8 \%)$ sedangkan sisanya 4 mahasiswa $(5,2 \%)$ masuk kategori usia $>25$ tahun. 


\section{Faktor jenis kelamin}

Jenis kelamin dalam penelitian ini diperoleh bahwa dari 77 responden sebagian besar berjenis kelamin laki-laki sebanyak 49 mahasiswa(63,6\%) sedangkan yang berjenis kelamin perempuan sebanyak 28 mahasiswa $(36,4)$.

\section{Faktor motivasi}

Motivasi responden dalam penelitian ini diperoleh bahwa dari 77 responden, yang memiliki motivasi tinggi sebanyak 44 mahasiswa $(57,1 \%)$ sedangkan sisanya 33 mahasiswa $(42,9 \%)$ memiliki motivasi rendah.

\section{Faktor pengalaman mengemudi}

Pengalaman mengemudi responden dalam penelitian ini diperoleh bahwa dari 77 responden sebagian besar memiliki pengalaman cukup ( $\geq 1$ tahun ) sebanyak 50 mahasiswa (64,9\%) sedangkan sisanya 27 mahasiswa $(35,1 \%)$ memiliki pengalaman kurang ( $\leq 1$ tahun).

\section{Analisis Bivariat}

Hubungan usia dengan persepsi tentang keselamatan berkendara

Tabel 1 Hubungan Usia dengan Persepsi Tentang Keselamatan Berkendara

\begin{tabular}{llllllll}
\hline \multirow{2}{*}{ Usia } & \multicolumn{4}{l}{ Persepsi keselamatan berkendara } & Total & \multirow{2}{*}{ Pvalue } \\
\cline { 2 - 6 } & \multicolumn{2}{l}{ Kurang Baik } & Baik & & \\
\cline { 2 - 6 } & $\mathrm{N}$ & $\%$ & $\mathrm{~N}$ & $\%$ & $\mathrm{~N}$ & $\%$ \\
\hline$<25$ & 19 & 26,0 & 54 & 74,0 & 73 & 100 & \multirow{2}{*}{1,000} \\
$\geq 25$ & 1 & 25,0 & 3 & 75,0 & 4 & 100 & \\
\hline Total & 20 & 26,0 & 57 & 74,0 & 77 & 100 &
\end{tabular}

Berdasarkan tabel 1 hasil analisis hubungan antara usia dengan persepsi keselamatan berkendara pada mahasiswa pengendara sepeda motor di STIKes Cirebon tahun 2014 diperoleh bahwa diantara 73 responden yang usia $<25$ tahun, terdapat 19 responden $(26,0 \%)$ yang berpersepsi yang kurang baik tentang keselamatan berkendara. Sedangkan diantara 4 responden yang usia $\geq 25$ tahun, terdapat 1 responden $(25,0 \%)$ yang berpersepsi kurang baik tentang keselamatan berkendara. Hasil uji statistik diperoleh nilai Pvalue 1,000. Hal ini menunjukan tidak ada hubungan yang bermakna antara usia dengan persepsi keselamatan berkendara.

\section{Hubungan jenis kelamin dengan persepsi tentang keselamatan berkendara}

Tabel 2. Hubungan Jenis Kelamin dengan Persepsi Tentang Keselamatan Berkendara

\begin{tabular}{llllllll}
\hline \multirow{2}{*}{$\begin{array}{l}\text { Jenis } \\
\text { Kelamin }\end{array}$} & \multicolumn{9}{l}{ Persepsi keselamatan berkendara } & \multirow{2}{*}{ Total } & \multirow{2}{*}{ Pvalue } \\
\cline { 2 - 6 } & \multicolumn{2}{l}{ Kurang Baik } & Baik & & & \\
\cline { 2 - 6 } & $\mathbf{N}$ & $\mathbf{\%}$ & $\mathbf{N}$ & $\mathbf{\%}$ & $\mathbf{N}$ & $\mathbf{\%}$ & \\
\hline Laki-laki & 12 & 24,5 & 37 & 75,5 & 49 & 100 & \multirow{2}{*}{0,902} \\
Perempuan & 8 & 28,6 & 20 & 71,4 & 28 & 100 & \\
\hline Total & 20 & 26,0 & 57 & 74,0 & 77 & 100 & \\
\hline
\end{tabular}

Berdasarkan tabel 2. hasil analisis hubungan antara jenis kelamin dengan persepsi keselamatan berkendara pada mahasiswa pengendara sepeda motor di STIKes Cirebon tahun 2014 diperoleh bahwa diantara 49 responden yang berjenis kelamin laki-laki, terdapat 12 responden $(24,5 \%)$ yang mempunyai persepsi yang kurang baik tentang keselamatan berkendara. Sedangkan diantara 28 responden yang berjenis kelamin perempuan, terdapat 8 responden $(28,6 \%)$ yang mempunyai persepsi kurang baik tentang keselamatan berkendara. 
Hasil uji statistik diperoleh nilai $p$ value 0,902. Hal ini menunjukan tidak ada hubungan yang bermakna antara jenis kelamin dengan persepsi keselamatan berkendara.

\section{Hubungan motivasi dengan persepsi tentang keselamatan berkendara}

Tabel 3. Hubungan Motivasi dengan Persepsi Tentang Keselamatan Berkendara

\begin{tabular}{llllllll}
\hline \multirow{2}{*}{ Motivasi } & \multicolumn{4}{l}{ Persepsi keselamatan berkendara } & Total & \multirow{2}{*}{ Pvalue } \\
\cline { 2 - 6 } & \multicolumn{2}{l}{ Kurang Baik } & \multicolumn{2}{l}{ Baik } & & \\
\cline { 2 - 6 } & $\mathrm{N}$ & $\%$ & $\mathrm{~N}$ & $\%$ & $\mathrm{~N}$ & $\%$ & \\
\hline Rendah & 13 & 39,4 & 20 & 60,6 & 33 & 100 & \multirow{2}{*}{0,039} \\
Tinggi & 7 & 15,9 & 37 & 84,1 & 44 & 100 & \\
\hline Total & 20 & 26,0 & 57 & 74,0 & 77 & 100 & \\
\hline
\end{tabular}

Berdasarkan tabel 3. hasil analisis hubungan antara motivasi dengan persepsi keselamatan berkendara pada mahasiswa pengendara sepeda motor di STIKes Cirebon tahun 2014 diperoleh bahwa diantara 33 responden yang memiliki motivasi rendah, terdapat 13 responden $(39,4 \%)$ yang berpersepsi yang kurang baik tentang keselamatan berkendara. Sedangkan diantara 44 responden yang memiliki motivasi tinggi, terdapat 7 responden $(15,9 \%)$ yang berpersepsi kurang baik tentang keselamatan berkendara. Hasil uji statistik diperoleh nilai $p$ value 0,039. Hal ini menunjukan ada hubungan yang bermakna antara motivasi dengan persepsi keselamatan berkendara.

\section{Hubungan pengalaman mengemudi dengan persepsi tentang keselamatan berkendara}

Tabel 4. Hubungan Pengalaman Mengemudi dengan Persepsi Tentang Keselamatan Berkendara

\begin{tabular}{|c|c|c|c|c|c|c|c|}
\hline \multirow{3}{*}{$\begin{array}{l}\text { Pengalaman } \\
\text { Mengemudi }\end{array}$} & \multicolumn{4}{|c|}{ Persepsi keselamatan berkendara } & \multirow{2}{*}{\multicolumn{2}{|c|}{ Total }} & \multirow{3}{*}{$\begin{array}{l}\mathrm{P} \\
\text { value }\end{array}$} \\
\hline & \multicolumn{2}{|c|}{ Kurang Baik } & \multicolumn{2}{|c|}{ Baik } & & & \\
\hline & $\mathrm{N}$ & $\%$ & $\mathrm{~N}$ & $\%$ & $\mathrm{~N}$ & $\%$ & \\
\hline Kurang & 4 & 14,8 & 23 & 85,2 & 27 & 100 & \\
\hline Cukup & 16 & 32,0 & 34 & 68,0 & 50 & 100 & 1,171 \\
\hline Total & 20 & 26,0 & 57 & 74,0 & 77 & 100 & \\
\hline
\end{tabular}

Berdasarkan tabel 4. hasil analisis hubungan antara pengalaman mengemudi dengan persepsi keselamatan berkendara pada mahasiswa pengendara sepeda motor di STIKes Cirebon tahun 2014 diperoleh bahwa diantara 27 responden yang memiliki pengalaman mengemudi kurang, terdapat 4 responden $(14,8 \%)$ yang berpersepsi yang kurang baik tentang keselamatan berkendara. Sedangkan diantara 50 responden yang memiliki pengalaman mengemudi cukup, terdapat 16 responden $(32,0 \%)$ yang berpersepsi kurang baik tentang keselamatan berkendara.

Hasil uji statistik diperoleh nilai $p$ value 1,171 . Hal ini menunjukan tidak ada hubungan yang bermakna antara pengalaman mengemudi dengan persepsi keselamatan berkendara.

\section{PEMBAHASAN}

\section{Persepsi tentang keselamatan berkendara}

Persepsi dalam arti sempit ialah penglihatan, bagaimana cara seseorang melihat sesuatu. Sedangkan dalam arti luas ialah pandangan atau pengartian yaitu bagaimana seseorang memandang atau mengartikan sesuatu. ${ }^{13}$ Persepsi keselamatan berkendara adalah pandangan, pendapat, dan penilaian responden dalam menafsirkan, mengartikan, pengetahuan tentang keselamatan berkendara (safety riding) untuk mencegah terjadinya risiko kecelakaan lalu lintas. ${ }^{14}$ Faktor-faktor yang mempengaruhi persepsi seseorang menurut Muchlas adalah usia dan jenis kelamin, sedangkan menurut Robbins diantaranya pengalaman dan motivasi. ${ }^{11,15}$ 
Safety riding merupakan suatu usaha yang dilakukan dalam meminimalisir tingkat bahaya dan memaksimalkan keselamatan dalam berkendara, demi menciptakan suatu kondisi yang mana kita berada pada titik membahayakan pengendara lain dan menyadari kemungkinan bahaya yang dapat terjadi di sekitar kita serta pemahaman akan pencegahan dan penanggulangannya. Faktor-faktor yang mempengaruhi persepsi tentang keselamatan berkendara antara lain usia, jenis kelamin, motivasi, dan pengalaman mengemudi. ${ }^{14}$

Hasil penelitian mengenai gambaran persepsi keselamatan berkendara berdasarkan distribusi persepsi keselamatan berkendara pada mahasiswa pengendara sepeda motor mempunyai persepsi baik tentang keselamatan berkendara lebih banyak. Hal ini kemungkinan setiap individu mempunyai persepsi baik tentang apa yang dilihat, didengar, dan dirasakannya yang selanjutnya kembali kepada individu tersebut untuk bagaimana mempraktekan hasil dari proses persepsi tersebut.

Persepsi menurut Sarwono merupakan kemampuan seseorang untuk mengorganisir suatu pengamatan. Dimana kemampuan tersebut kemampuan untuk membedakan, kemampuan untuk mengelempokan, dan kemampuan untuk memfokuskan. Setiap orang bisa saja mempunyai persepsi yang berbeda meskipun objeknya sama. Hal ini dimungkinkan karena adanya perbedaan dalam sistem nilai dan ciri kepribadian dari individu yang bersangkutan. ${ }^{16}$ Oleh karena itu pada suatu penelitian tidak menutup kemungkinan bahwa hasil yang didapat dalam penelitian tentang persepsi keselamatan berkendara ini berbeda dengan penelitian yang dilakukan oleh peneliti lain dikarenakan kemampuan membedakan, menilai, mengamati sesuatu dan ciri kepribadian seseorang dalam mempersepsikan tentang keselamatan berkendara itu berbeda-beda setiap orang.

Persepsi risiko tidak hanya meliputi pemeriksaan potensi bahaya di lingkungan lalu lintas tetapi juga pemeriksaan kemampuan pengemudi dan kendaraan untuk mencegah potensi bahaya dari tabrakan yang sesungguhnya. Persepsi risiko juga merupakan kemampuan untuk mengidentifikasi faktor risiko yang relevan dan kemampuan untuk mengatasi resiko tersebut. ${ }^{17}$

\section{Faktor usia}

Usia merupakan salah satu faktor yang diduga mempengaruhi persepsi tentang keselamatan berkendara pada responden. Menurut Muchlas menyatakan bahwa usia merupakan faktor yang mempengaruhi seseorang berpersepsi tentang suatu objek. ${ }^{11}$ Hal ini karena responden adalah mahasiswa regular yang kemungkinan mempunyai pemahaman baik tentang keselamatan berkendara.

Hasil uji statistik Pvalue $=1,000(\mathrm{P}>\alpha)$ yang menunjukan Ho ditolak maka tidak ada hubungan bermakna antara usia dengan persepsi tentang keselamatan berkendara pada mahasiswa pengendara sepeda motor di STIKes Cirebon tahun 2014. Didukung dengan penelitian yang dilakukan oleh Hikmah pada tahun 2008, menyebutkan bahwa tidak ada hubungan yang bermakna antara usia dengan persepsi terhadap komunikasi terapeutik dengan $p$ value sebesar 0,265. Menurutnya hal ini dikarenakan distribusi responden yang tidak merata diantara kedua kategori dan dapat pula dikarenakan jumlah sampel yang cukup kecil. ${ }^{18}$

Penelitian ini tidak sejalan dengan Faradina pada tahun 2007 yang berpendapat bahwa ada hubungan yang bermakna anatara usia dengan persepsi supir bajaj. ${ }^{8}$ Ini dikarenakan perbedaan pada usia responden yang diteliti dan kemungkinan ada faktor lain yang mempengaruhi misalnya tingkat pengetahuan dan tingkat pendidikan pada responden.

Dengan demikian kemungkinan faktor usia merupakan bukan faktor yang berpengaruh besar terhadap persepsi seseorang agar dapat mengemudi kendaraannya dengan baik, pengemudi yang berusia $<25$ tahun mempunyai perkembangan kejiwaan yang belum stabil sehingga kecenderungan lebih emosional dalam mengendalikan kendaraan.

\section{Faktor jenis kelamin}

Jenis kelamin merupakan salah satu faktor yang diduga mempengaruhi persepsi tentang keselamatan berkendara pada responden. Menurut Muchlas menyatakan bahwa jenis kelamin 
merupakan faktor yang mempengaruhi seseorang berpersepsi tentang suatu objek. ${ }^{11}$ Hal ini karena responden dengan jenis kelamin laki-laki kemungkinan akan berasa lebih percaya diri ketika pergi ke kampus menggunakan kendaraan.

Hasil uji statistik Pvalue $=0,902(\mathrm{P}>\alpha)$ yang menunjukan Ho ditolak maka tidak ada hubungan bermakna antara jenis kelamin dengan persepsi tentang keselamatan berkendara pada mahasiswa pengendara sepeda motor di STIKes Cirebon tahun 2014. Penelitian ini sejalan dengan penelitian Salihat tahun 2009, yang mengatakan bahwa tidak ada hubungan antara jenis kelamin dengan persepsi resiko keselamatan berkendara. ${ }^{7}$

Hal ini kemungkinan dikarenakan adanya faktor lain misalnya pengaruh teman dalam mengasumsikan risiko yang dihadapinya. Selain itu frekuensi mengendarai kendaraan dapat mempengeruhi persepsi responden terhadap resiko keselamatan.

\section{Faktor motivasi}

Pada penelitian ini, motivasi diduga sebagai salah satu faktor yang mempengaruhi persepsi tentang keselamatan berkendara pada responden. Menurut Robbins menyatakan bahwa motivasi merupakan faktor yang mempengaruhi seseorang berpersepsi tentang suatu objek. ${ }^{15}$

Hasil uji statistik Pvalue $=0,039(\mathrm{P}<\alpha)$ yang menunjukan Ho diterima maka ada hubungan bermakna antara motivasi dengan persepsi tentang keselamatan berkendara pada mahasiswa pengendara sepeda motor di STIKes Cirebon tahun 2014. Penelitian ini sesuai dengan penelitian yang dilakukan oleh Wayka Putri pada tahun 2011, yang menyatakan adanya hubungan antara motivasi dengan persepsi. Menurutnya semakin baik tingkat motivasi pekerja terhadap resiko K3 maka semakin baik pula persepsi pekerja tehadap risiko K3, begitu pula sebaliknya semakin buruk tingkat motivasi pekerja terhadap risiko K3 maka semakin buruk juga persepsi pekerja tersebut terhadap risiko $\mathrm{K} 3 .{ }^{19}$

Penelitian ini tidak sejalan dengan Faradina pada tahun 2007 yang berpendapat bahwa tidak ada hubungan yang bermakna antara motivasi dengan persepsi supir bajaj. ${ }^{8}$ Hal ini dikarenakan kemungkinan terdapat perbedaan tingkatan kebutuhan dimana responden berada pada tingkatan yang berbeda hal ini menyebabkan perbedaan antara motivasi tinggi dengan motivasi rendah terhadap persepsi tentang keselamatan berkendara.

Dengan demikian penelitian ini sesuai dengan teori yang dikemukakan oleh Robbins menyatakan bahwa motivasi merupakan faktor yang mempengaruhi seseorang berpersepsi tentang suatu objek. ${ }^{15}$

\section{Faktor pengalaman mengemudi}

Pengalaman mengemudi merupakan salah satu faktor yang diduga mempengaruhi persepsi tentang keselamatan berkendara pada responden. Menurut Robbins menyatakan salah satu faktor yang mempengaruhi persepsi seseorang tentang sesuatu adalah pengalaman. ${ }^{15}$ Hal tersebut bisa terjadi dikarenakan jumlah pengendara dengan pengalaman mengemudi motor $>1$ tahun lebih dominan yaitu sebanyak 50 orang dari 77 .

Hasil uji statistik Pvalue $=1,171(\mathrm{P}>\alpha)$ yang menunjukan Ho ditolak maka tidak ada hubungan bermakna antara pengalaman dengan persepsi tentang keselamatan berkendara pada mahasiswa pengendara sepeda motor di STIKes Cirebon tahun 2014. Hasil penelitian ini sejalan dengan penelitian yang dilakukan oleh Zainal Arifin 2011, yang menyatakan bahwa tidak ada hubungan yang bermakna antara pengalaman mengemudi dengan persepsi tentang keselamatan berkendara. ${ }^{14}$ Hal ini kemungkinan karena responden yang diteliti sama yaitu mahasiswa.

Penelitian ini tidak sejalan dengan Faradina pada tahun 2007 yang berpendapat bahwa ada hubungan yang bermakna anatara motivasi dengan persepsi supir bajaj. ${ }^{8}$ Hal ini dikarenakan pengalaman akan mendorong untuk melakukan sesuatu yang baik dan kemungkinan adanya pola fikir yang berbeda pada masing-masing responden.

Dengan demikian kemungikan faktor pengalaman mengemudi bukan juga faktor yang berpengaruh besar terhadap persepsi seseorang agar dapat mengemudi kendaraannya dengan baik. 


\section{SIMPULAN}

Hasil penelitian mengenai "Faktor-faktor yang berhubungan dengan persepsi tentang keselamatan berkendara pada mahasiswa pengendara sepeda motor di STIKes Cirebon tahun 2014" sebagai berikut:

1. Gambaran responden yang memiliki persepsi baik tentang keselamatan berkendara yaitu sebanyak 57 responden $(74,0 \%)$, responden yang memiliki usia $<25$ tahun lebih banyak yaitu 73 responden $(94.8 \%)$, jenis kelamin laki-laki lebih banyak yaitu 49 responden $(63,6 \%)$, motivasi tinggi lebih banyak yaitu 44 responden $(57,1 \%)$, dan pengalaman mengemudi cukup lebih banyak yaitu 50 responden $(64,9 \%)$.

2. Tidak ada hubungan antara usia dengan persepsi tentang keselamatan berkendara pada mahasiswa pengendara sepeda motor di STIKes Cirebon tahun 2014.

3. Tidak ada hubungan antara jenis kelamin dengan persepsi tentang keselamatan berkendara pada mahasiswa pengendara sepeda motor di STIKes Cirebon tahun 2014.

4. Ada hubungan antara motivasi dengan persepsi tentang keselamatan berkendara pada mahasiswa pengendara sepeda motor di STIKes Cirebon tahun 2014.

5. Tidak ada hubungan antara pengalaman mengemudi dengan persepsi tentang keselamatan berkendara pada mahasiswa pengendara sepeda motor di STIKes Cirebon tahun 2014.

\section{SARAN}

1. Bagi mahasiswa pengendara sepeda motor di STIKes Cirebon, harus meningkatkan kesadaran bahwa keselamatan berkendara merupakan kebutuhan yang utama sehingga dapat menumbuhkan motivasi untuk menerapkan safety riding saat berkendara.

2. Bagi kampus STIKes Cirebon, agar dapat menjalin kerjasama dengan pihak Polri dalam menyelenggarakan kampanye, kegiatan promosi, himbauan, dan seminar untuk menambah pengalaman, pengetahuan tentang baiknya menerapkan safety riding, dan bahaya yang bila tidak menerapkannya bagi pengendara motor khususnya pada mahasiswa diharapkan motivasinya meningkat dengan timbul kesadaran akan keselamatan dirinya.

3. Bagi peneliti selanjutnya diharapkan mengikutsertakan variabel-variabel lain yang tidak terdapat pada penelitian ini.

\section{DAFTAR PUSTAKA}

1. Anonim. Berapa jumlah sepeda motor di Indonesia 2013 yang menggunakan sabuk bonceng?; [diakses tanggal 30 Mei 2014]. Diunduh dari: www.igcomputer.com/berapa jumlah-sepedamotor-di-indonesia-2013-yuang-menggunakan-sabuk-bonceng.html.

2. Anonim. Kecelakaan lalu lintas menjadi pembunuh terbesar ketiga; [diakses tanggal 27 Mei 2014]. Diunduh dari: http://www.bin.go.id

3. Anonim. Pada 2013, 23.385 tewas kecelakan lalu lintas; [diakses tanggal 30 Mei 2014]. Diunduh dari:www.gatra.com/hukum-I/44540-pada-2013,-23-385-tewas-kecelakaanlalulintas, html

4. Anonim. Lagi, sepeda motor dominasi kecelakaan di Jakarta; [diakses tanggal 30 Mei 2014]. Diunduh dari: http://www.edo rusyanto@blogspot.com

5. Anonim. Laka lantas dan kriminalitas tahun 2013 di kota cirebon naik; [diakses tanggal 27 Mei 2014]. Diunduh dari:www.cirebontrust.com

6. Anonim.Waspada bagi pengendara motor; [diakses tanggal 30 Mei 2014]. Diunduh dari: www.ani rahmani@blogspot.com

7. Salihat, Ing Kurnia. Persepsi terhadap risiko berkendara dengan penggunaan sabuk keselamatan selama berkendara pada mahasiswa universitas Indonesia tahun 2009. Skripsi. Depok: FKM UI; 2009

8. Faradina, Triska. Gambaran persepsi supir bajaj daerah pangkalan blok M terhadap kesehatan berkendara di jalan raya tahun 2007. Skiripsi. Depok: FKM UI; 2007 
9. Yulianti. Faktor-faktor yang berhubungan dengan persepsi supir angkutaan umum jurusan parung-bogor tentang keselamatan berkendara di jalan raya tahun 2010. Skripsi. Bogor. FKIK Universitas Islam Negeri Syarif Hidayatullah; 2010

10. Prasilika Tiasa. Studi persepsi risiko keselamatan berkendara serta hubungan dengan locus of control pada mahasiswa FKM UI yang mengendarai motor tahun 2007. Skripsi. Depok: FKM $\mathrm{UI} ; 2007$

11. Muchlas, Makmuri. Perilaku organisasi. Yogyakarta: Gajah Mada University Press; 2005

12. Riyanto, Agus. Aplikasi metodologi penelitian kesehatan. Yogyakarta: Nuha medika; 2011

13. Notoatmodjo. Pendidikan dan perilaku kesehatan, Jakarta: Rineka Cipta;2003

14. Zainal Arifin, Mohamad. Hubungan persepsi dengan keselamatan berkendara pada civitas akademika pengendara motor di UIN syarif hidayatullah Jakarta tahun 2011. Skripsi. Jakarta: Fakultas kedokteran dan ilmu kesehatan; 2011

15. Robbins, Stephen. Prinsi-prinsip perilaku organisasi. Edisi 5. Jakarta: Erlangga;2002

16. Sarwono, Sarlito Wirawan. Pengantar umum psikologi. Jakarta: PT Bulan Bintang;1998

17. Anonim.Safety riding community; [diakses tanggal 08 Agustus 2014].Diunduh dari: http:saft7.com

18. Hikmah, Syara. Persepsi staf mengenai patient safety di Ird Rsud Fatmawati tahun 2008. Skripsi. Depok: FKM UI; 2008

19. Wayka Purti. Analisis faktor yang berhubungan dengan persepsi resiko keselamatan kerja pada pekerja PT MEDCO E\&P Indonesia Rimau Asset tahun 2011. Skripsi. Depok: Kesmas K3; 2011 